Provided for non-commercial research and education use. Not for reproduction, distribution or commercial use.

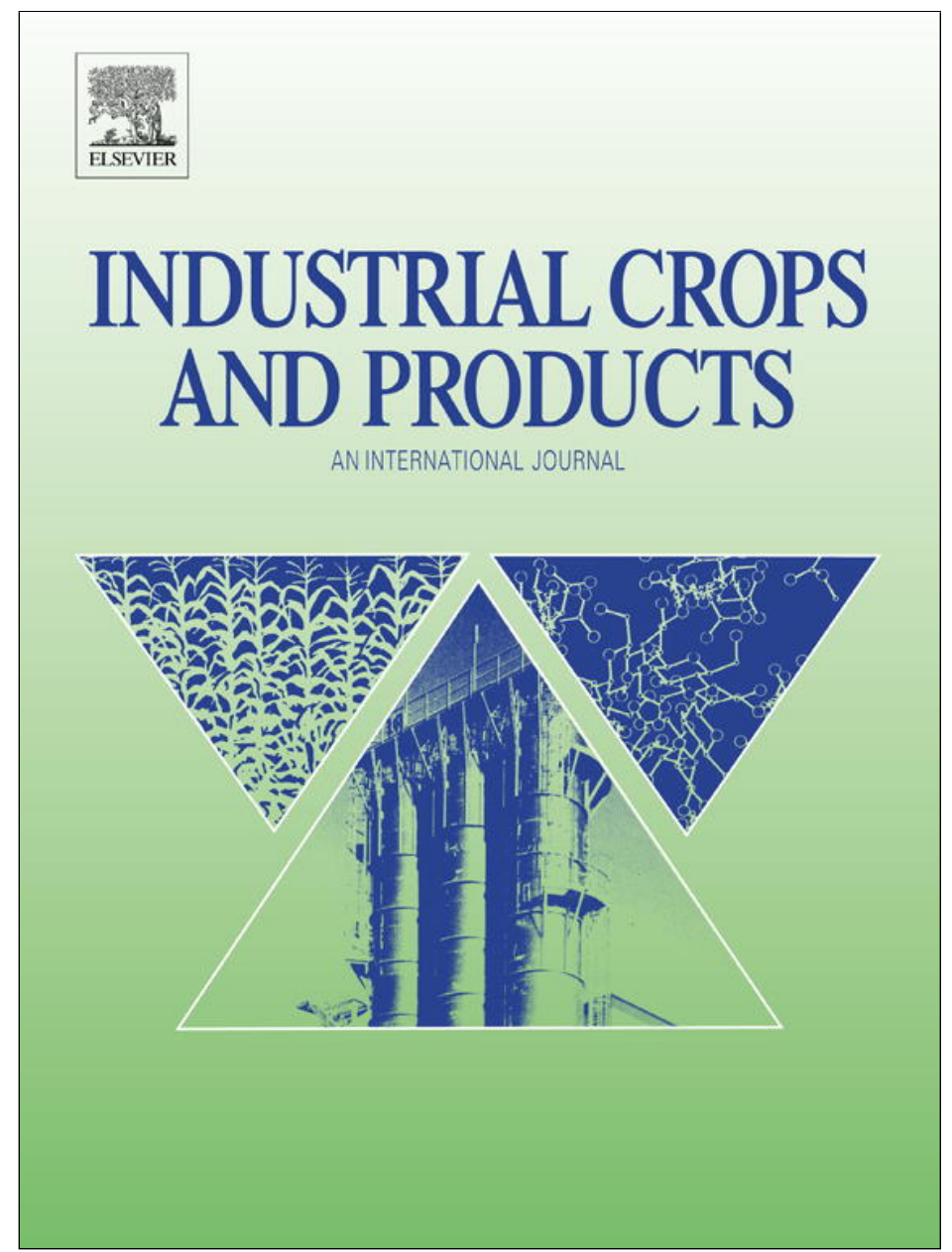

(This is a sample cover image for this issue. The actual cover is not yet available at this time.)

This article appeared in a journal published by Elsevier. The attached copy is furnished to the author for internal non-commercial research and education use, including for instruction at the authors institution and sharing with colleagues.

Other uses, including reproduction and distribution, or selling or licensing copies, or posting to personal, institutional or third party websites are prohibited.

In most cases authors are permitted to post their version of the article (e.g. in Word or Tex form) to their personal website or institutional repository. Authors requiring further information regarding Elsevier's archiving and manuscript policies are encouraged to visit:

http://www.elsevier.com/copyright 


\title{
Extraction, identification and quantitative HPLC analysis of flavonoids from sarang semut (Myrmecodia pendan)
}

\author{
Adam Mekonnen Engida ${ }^{a}$, Novy S. Kasim ${ }^{a}$, Yeshitila Asteraye Tsigie ${ }^{a}$, Suryadi Ismadji ${ }^{\mathrm{b}}$, \\ Lien Huong Huynh ${ }^{\mathrm{c}}$, Yi-Hsu Ju ${ }^{\mathrm{a}, *}$ \\ a Department of Chemical Engineering, National Taiwan University of Science and Technology, 43, Sec. 4, Keelung Road, Taipei 106-07, Taiwan \\ ${ }^{b}$ Department of Chemical Engineering, Widya Mandala Surabaya Catholic University, Kalijudan 37, Surabaya 60114, Indonesia \\ c Department of Chemical Engineering, Can Tho University, Can Tho City, Viet Nam
}

\section{A R T I C L E I N F O}

\section{Article history:}

Received 11 December 2011

Received in revised form 22 April 2012

Accepted 27 April 2012

\section{Keywords:}

Antioxidant activity

Flavonoids

HPLC-UV/vis

Myrmecodia pendan

Phenolics content

\begin{abstract}
A B S T R A C T
The objective of this study was to extract and determine total contents of phenolic and flavonoid compounds as well as to identify and quantify some flavonoids from sarang semut (Myrmecodia pendan). Water bath extraction at $55^{\circ} \mathrm{C}$ was employed for extracting flavonoids from sarang semut. The effects of parameters such as extraction time, composition of solvent mixture and solvent to sample ratio on extraction were investigated. From $\left(3^{3}\right)$ factorial design the optimum extracting parameters were determined as follows: extraction time, $4 \mathrm{~h}$; ethanol/water composition, $80 \%$; and solvent to sample ratio, $50 \mathrm{ml} / \mathrm{g}$. Under these optimal conditions, a yield of $13.82 \%$ was obtained. The free radical scavenging activity (antioxidant activity) of the extract was evaluated using DPPH radical and it was found that the $\mathrm{IC}_{50}$ occurred at $96.21 \pm 9.03 \mu \mathrm{g} / \mathrm{ml}$ of extract. The total phenol and flavonoid contents were determined using designed methods and found to be $330.61 \pm 2.13 \mathrm{mg} \mathrm{GAE} / \mathrm{g}$ and $63.28 \pm 1.75 \mathrm{mg} \mathrm{QE} / \mathrm{g}$ of dry extract, respectively. The extract obtained under optimum conditions was analyzed by HPLC and five flavonoid compounds were identified and quantified; they are kaempferol $(13.767 \mathrm{mg} / \mathrm{g})$, luteoline $(0.005 \mathrm{mg} / \mathrm{g})$, rutine $(0.003 \mathrm{mg} / \mathrm{g})$, quercetin $(0.030 \mathrm{mg} / \mathrm{g})$ and apigenin $(4.700 \mathrm{mg} / \mathrm{g})$ of dry extract.
\end{abstract}

(c) 2012 Elsevier B.V. All rights reserved.

\section{Introduction}

Flavonoids represent a highly diverse class of secondary plant metabolites with about 9000 structures (Martens and Mithofer, 2005). Flavonoids are polyphenolic compounds derived from 2-phenylchromane commonly found in many plants, vegetables, and flowers (Boue et al., 2003; Plochmann et al., 2007; Androutsopoulos et al., 2010; Lisa et al., 2010). They received considerable attention in literature, specifically due to their biological and physiological importance (Zin et al., 2002; Rijk et al., 2006). They have benefits to human health, including antioxidant activities (Tian et al., 2009), metal chelation (Heim et al., 2002; Seyoum et al., 2006) and antiproliferative, anticarcinogenic, antibacterial, anti-inflammatory, antialergic, and antiviral effects (Merken and Beecher, 2000; Ajila et al., 2010; Abrham et al., 2008; Barreca et al., 2011). Flavonoids are able to scavenge free radicals directly by hydrogen atom donation (Prochazkova et al., 2011). Basically flavonoids are derivatives of 1,3-diphenylpropane-1-one $\left(C_{6}-C_{3}-C_{6}\right)$ (Erlund, 2004; Barontini et al., 2010; Biesaga, 2011). Derived from the chalcone structure, a flavonoid class containing

\footnotetext{
* Corresponding author. Tel.: +8862 27376612; fax: +8862 27376644 .

E-mail address: yhju@mail.ntust.edu.tw (Y.-H. Ju).
}

three rings can be formed (Martens and Mithofer, 2005; Mladenka et al., 2010).

One of the not-well identified medicinal plants is sarang semut (Myrmecodia pendan) which might be a new potential source of therapeutic agents. Sarang semut lives as epiphyte on cajupu (Melaleuca), cemara gunung (Casuarina), kaha (Castanopsis) and beech (Nothophagus). It is called sarang semut since the inner part of its hypocotyls is used as nest by ants (sarang is nest and semut is ant in Bahasa Indonesian). It belongs to genus Iridomyrmex. Most sarang semut plants are usually colonized by one species of ant. $M$. pendans is colonized by ant Ochetellus species. Sarang semut is a member of Rubiaceae family with five genera. However, only two of which have association with ants. They are Myrmecodia (45 species) and Hypnophytum (26 species). Hypnophytum formicarum, $M$. pendans and $M$. tuberose are believed to have medicinal value (Soeksmanto et al., 2010).

There is no report on identification or quantification of bioactive compounds in sarang semut plant, only reports on discussing about its ecology; taxonomy and ethno botany can be found (Soeksmanto et al., 2010). Anti-cancer activity of this plant was tested by using cancer cells derived from human cervix and canine breast, called HeLa cells and MCM-B2, respectively (Soeksmanto et al., 2010). The result of the research showed that the extract of sarang semut plant was capable of inhibiting the growth of HeLa and MCM-B2 cells. 
This effect may be the result of phenolic compounds especially flavonoids contained in the tested extracts.

Hence the objective of this research was to extract and determine total phenolic and flavonoid contents using experimental design methods, as well as to identify and determine some individual flavonoids from sarang semut (M. pendan).

\section{Materials and methods}

\subsection{Chemicals and materials}

The plant material used in this study was obtained from a traditional medicine plant store in Wamena, Papua, Indonesia. Ethanol, methanol (MeOH, HPLC grade), acetic acid (glacial analytical grade), tert-butyl hydroquinone (TBHQ) and flavonoid standards including catechin, (+)-epicatechin, apigenin, luteolin, myricetin, quercetin and rutine were purchased from Sigma Aldrich, USA. Deionized water was used for HPLC mobile phase.

\subsection{Sample preparation}

Sarang semut was washed with running tap water and then rinsed by distilled water to remove any adsorbed contaminant from sample surface. The cleaned sample was chopped and dried using freeze dryer then placed in an oven at $40{ }^{\circ} \mathrm{C}$ for $12 \mathrm{~h}$ to remove any remaining moisture. The dried material was ground by a blender into powder and passed through a sieve ( 120 meshes) was collected for extraction.

\subsection{Extraction}

Heat reflux is the most common method for the extraction of bioactive components from natural products (Xiao et al., 2008). This extraction method was chosen for the first preliminary study because of its simplicity and manageability. The dried and powdered plant material ( $1 \mathrm{~g}$ per batch) was extracted using water bath at $55^{\circ} \mathrm{C}$. Three independent variables and three levels; solvent composition $(40 \%, 60 \%, 80 \%$ of ethanol), extraction time (2, 3, $4 \mathrm{~h})$, and solvent to sample ratio $(30,40,50 \mathrm{ml} / \mathrm{g})$ with coded values as minimum ( -1$)$, center ( 0 ) and maximum (1) were evaluated. All these factors might affect the diffusion of analytes from sample matrix to solvent. Experiments were conducted with full factorial design $\left(3^{3}\right)$ which refers to three independent variables studied. Three levels were conducted for each independent variable. Altogether, 27 runs were performed under randomized order and the experiments on each sample were carried out in triplicate. The mixture was filtered with a Whatman No. 2 filter paper; ethanol was removed using a rotary evaporator at $68^{\circ} \mathrm{C}$ and water was removed by freeze drying. The percentage of crude dry extract was determined as follows:

$Y_{\text {extract }}(\%)=\left(\frac{M_{\text {extract }}}{m_{\text {feed }}}\right) \times 100$

where $Y_{\text {extract }}$ is the extraction yield, $M_{\text {extract }}$ is the crude extract mass $(\mathrm{g})$ and $m_{\text {feed }}$ is the feed mass $(\mathrm{g})$

\subsection{DPPH radical scavenging activity assay}

Free radical scavenging activity of the plant extract was determined by using DPPH assay according to the procedure described by Basma et al. (2011), with some modifications. 2,2-Diphenyl-1picrylhydrazyl (DPPH) $0.002 \%$ methanolic solution was prepared in a volumetric flask covered with aluminum foil. One milliliter of the plant extract in methanol $(10-150 \mu \mathrm{g} / \mathrm{ml})$ was mixed with $1 \mathrm{ml}$ solution of DPPH (0.002\%). For blank solution, the extract was substituted by methanol. Reduction of DPPH by antioxidants was monitored at $520 \mathrm{~nm}$ using a spectrophotometer (Jasco,
UV-550, Japan) in $10 \mathrm{~mm}$ quartz cells. Anti-radical activity was based on measurement of the reducing ability of the plant extract toward DPPH radical. Scavenging effect was calculated as $\left(A_{0}-A_{\mathrm{t}}\right) \times 100 / A_{0}$, where $A_{0}$ is the absorbance of the control reaction and $A_{\mathrm{t}}$ is the absorbance in the presence of the extract sample. The effective concentration of the plant extract at which $50 \%$ of $\mathrm{DPPH}$ radicals are reduced $\left(\mathrm{IC}_{50}\right)$ was calculated graphically using a calibration curve in the linear range by plotting extract concentration vs. the corresponding scavenging effect. Data were reported as arithmetic means \pm SD for three replications. The performance of the extracts was also compared with that of ascorbic acid.

\subsection{Determination of total phenolics content}

The total phenolics content of the plant extract was determined by Folin-Ciocalteu reagent (FCR) method according to Michel et al. (2011). For a $2.00 \mathrm{ml}$ total volume, $20 \mu \mathrm{l}$ of extract, $20 \mu \mathrm{l}$ of aqueous standard solutions $(100-1000 \mu \mathrm{g} / \mathrm{ml}$ of gallic acid) or $20 \mu \mathrm{l}$ deionized water for blank were first mixed with $100 \mu$ l of FCR after adding $1.58 \mathrm{ml}$ deionized water and the contents were kept at room temperature $\left(26.5^{\circ} \mathrm{C}\right)$ for $10 \mathrm{~min}$. Later $300 \mu \mathrm{l}$ of $\mathrm{Na}_{2} \mathrm{CO}_{3}$ aqueous solution (20\%) was added between 8 and $15 \mathrm{~min}$ and incubated at room temperature for $20 \mathrm{~min}$. The absorbance was measured at $765 \mathrm{~nm}$ using a spectrophotometer (Jasco, UV-550, Japan). Total phenolics content was expressed as $\mu \mathrm{g}$ of gallic acid equivalent/g of dry extract ( $\mu \mathrm{g} \mathrm{GAE} / \mathrm{g}$ ).

\subsection{Determination of total flavonoid content}

Total flavonoid content of the plant extract was determined using aluminum chloride colorimetric method and using standard solutions $(12.5,25,50,80$ and $100 \mu \mathrm{g} / \mathrm{ml}$ of quercetin in $80 \%$ methanol). For the analysis, $1 \mathrm{ml}$ extract solution in $80 \%$ methanol $(1 \mathrm{mg} / \mathrm{ml})$ was mixed with $0.5 \mathrm{ml} 95 \%$ ethanol $(\mathrm{v} / \mathrm{v}), 0.1 \mathrm{ml}$ aluminum chloride solution $\left(10 \% \mathrm{AlCl}_{3}\right), 0.1 \mathrm{ml} 1 \mathrm{M}$ potassium acetate and $0.8 \mathrm{ml}$ distilled water to a total volume of $2.5 \mathrm{ml}$. The mixture was well mixed and incubated at room temperature for $30 \mathrm{~min}$. Absorbance was measured at $520 \mathrm{~nm}$ vs. reagent blank containing water instead of sample. Quercetin was used as the standard for the quantification of total flavonoid. Results were expressed as milligrams of quercetin equivalent per gram of dry weight extract ( $\mathrm{mg}$ $\mathrm{QE} / \mathrm{g}$ ). Total content of flavonoid was calculated as follows: Total flavonoid content $=\mathrm{QE} \times V / \mathrm{m}$. Where $\mathrm{QE}$ is the quercetin equivalence $(\mathrm{mg} / \mathrm{ml})$ or concentration of quercetin solution established from the calibration curve; $V$ is the volume of extract $(\mathrm{ml})$ and $m$ is the weight ( $\mathrm{g}$ ) of the dry extract (Basma et al., 2011). Data was reported as arithmetic mean \pm SD for three replications.

\subsection{Analysis of flavonoids by HPLC}

HPLC is one of the most powerful tools in analytical chemistry, with the ability to separate, identify and quantify the target compounds present in any sample that can be dissolved in HPLC compatible liquid (Chiu et al., 2002; Marston, 2007). Sarang semut plant sample was extracted at optimum condition for HPLC analysis using the method of Weisz et al. (2009). A sample ( $3 \mathrm{~g}$ ) was heated for $4 \mathrm{~h}$ in $150 \mathrm{ml}$ solvent at $55^{\circ} \mathrm{C}$. The mixture was filtered with a Whatman No. 2 filter paper, then ethanol was removed using a rotary evaporator at $60^{\circ} \mathrm{C}$ and water was removed by freeze drying. The dried extract was reconstituted and heated at $80^{\circ} \mathrm{C}$ for $1 \mathrm{~h}$ (to hydrolyze glycosides to aglycons) in a solution of $40 \mathrm{ml} 65 \%$ aqueous methanol in which $0.5 \mathrm{~g} / 1$ tert-butylhydroquinone (TBHQ) was dissolved, and $10 \mathrm{ml} 6 \mathrm{~N} \mathrm{HCl}$ was added. TBHQ was incorporated as antioxidant to avoid flavonoid degradation. After cooling, the solution was sonicated for $5 \mathrm{~min}$ and made to a final volume of $100 \mathrm{ml}$ by adding de-ionized water, then filtered through a $0.2 \mu \mathrm{m}$ Anotop 
Table 1

Extraction yield obtained under the experimental condition using complete randomized design (CRD) full factorial.

\begin{tabular}{|c|c|c|c|c|}
\hline \multirow[t]{2}{*}{ Independent variables } & \multicolumn{3}{|c|}{ Average \% yield at each level } & \multirow{2}{*}{$\begin{array}{l}\text { Range } \\
R^{\mathrm{b}}\end{array}$} \\
\hline & Level $1^{\mathrm{a}}$ & Level $2^{\mathrm{a}}$ & Level $3^{a}$ & \\
\hline Solvent composition (\%) & $10.08 \pm 2.84$ & $10.67 \pm 1.41$ & $11.56 \pm 1.89$ & $1.48 \pm 3.41$ \\
\hline Extraction time $(\mathrm{h})$ & $9.76 \pm 1.28$ & $11.19 \pm 1.42$ & $11.36 \pm 1.21$ & $1.60 \pm 1.76$ \\
\hline Solvent amount (ml/g) & $8.66 \pm 1.61$ & $11.54 \pm 1.31$ & $12.82 \pm 0.34$ & $3.16 \pm 1.65$ \\
\hline
\end{tabular}

average response for each level on extraction yield $(n=3)$.

b Range $(R)$ value means range between average yields for each level of extraction yield.

syringe filter for HPLC analysis. The HPLC analyses were performed with: Luna $5 \mathrm{U}-\mathrm{C} 18(2) 100 \mathrm{~A}$ column $(250 \mathrm{~mm} \times 4.5 \mathrm{~mm}, 5 \mu \mathrm{m})$ plus Jasco, quaternary gradient pump (pu-2089) plus Jasco, UV-2077 $4 \lambda$ intelligent $U V / v i s$ detector. The compounds were eluted with a gradient elution of mobile phases A and B. Solvent A consisted of deionized water and $1 \%$ acetic acid and solvent $B$ consisted of methanol (HPLC grade) and $1 \%$ acetic acid. Acetic acid (1\%) was added to reduce peak tailing. Gradient elution program was set as follows: $10 \% \mathrm{~B}-17.2 \% \mathrm{~B}$ (18 min), 17.2\% B-23\% B (12 min), 23\% B isocratic (10 min), 23\%-31.3\% B (13 min), 31.3\% B-46\% B (12 min), 46\% B-55\% B ( $5 \mathrm{~min}), 55 \%$ B-100\% B ( $5 \mathrm{~min}), 100 \%$ B isocratic (8 min), $10 \% \mathrm{~B}(2 \mathrm{~min})$ and $10 \% \mathrm{~B}$ isocratic $(5 \mathrm{~min})$. The injection volume for all samples was $20 \mu$ l. Flavonoids were monitored at $280 \mathrm{~nm}$ and $285 \mathrm{~nm}$ at a flow rate of $1 \mathrm{ml} / \mathrm{min}$. All determinations were performed in triplicate.

The flavonoids standard stock solutions were initially prepared. Dilutions and injections of these standards were then made until a HPLC chromatogram showed that the flavonoids peak height reached at $\mathrm{S} / \mathrm{N}$ of approximately $10: 1$ and $3: 1$ for LOQ and LOD solutions, respectively.

Flavonoids were identified by matching the retention time and their spectral characteristics against those of standards and the contents of flavonoids were determined using calibration curves. Each standard solution $(0.1-2.0 \mu \mathrm{g} / \mathrm{ml}$ quercetin, $0.1-0.5 \mathrm{mg} / \mathrm{ml}$ apigenin and rutine, $0.05-0.5 \mu \mathrm{g} / \mathrm{ml}$ luteoline and $0.01-0.1 \mathrm{mg} / \mathrm{ml}$ kaepferol) was dissolved in methanol and subjected to HPLC analysis. The calibration curves were constructed by plotting the average peak areas vs. the concentration of each analyte. The chromatogram for the blank solvent was subtracted from sample chromatogram to correct the background error. Finally the quantity of each detected flavonoid was determined using regression equation $(Y=a x \pm b)$, where $x$ is concentration and $y$ is the peak area of each flavonoid derived from calibration curve of each respective standard. The linearity was established by the coefficient of determination $\left(R^{2}\right)$. Slope, intercept, $R^{2}$ and the other statistical calibration lines were calculated using Microsoft excel version 7.0.

\section{Results and discussion}

\subsection{Optimization of extraction condition}

To obtain an efficient extraction of target compounds, optimization of experimental conditions is a critical step in developing an extraction method. The extraction efficiency of water bath extraction was examined at different sets of solvent composition, extraction time and solvent to sample ratio under $\left(3^{3}\right)$ test design. The results shown in Table 1 indicate that there are differences in yield among each set of extraction condition. As can be seen from Table 1, with increasing ethanol composition, extraction time and solvent to sample ratio from $40 \%$ to $60 \%, 2-4 \mathrm{~h}$ and $30-50 \mathrm{ml} / \mathrm{g}$, respectively; the yield (\%) varies from $10.08 \pm 2.84$ to $11.556 \pm 1.89$, $9.76 \pm 1.28$ to $11.36 \pm 1.21$ and $8.66 \pm 1.61$ to $12.82 \pm 0.34$ correspondingly. Statistically the variation was significant with $95 \%$ confidence level $(p=0.047)$. Extraction yield increases with increasing level of factors but solvent to sample ratio was found to be the most important determinant of yield with range $3.16 \pm 1.65$ as shown in Fig. 1. Mean values at the three levels for each parameter show how extraction yield changes with level of parameter. Based on the obtained mean value of main effects of the three most important factors, the highest extraction yield was obtained at $80 \%$ ethanol, $4 \mathrm{~h}$ and a solvent to sample ratio of $50 \mathrm{ml} / \mathrm{g}$. The maximum yield was obtained at highest levels of all factors. This illustrates the possibility of extracting more antioxidants from the plant on other higher combination of these factors and its potential as antioxidant compound source. But for this preliminary experiment the yield obtained was considered for further analysis.

Dry extract obtained under optimum condition was used for the analysis. Data were subjected to analyses of variance (ANOVA) and multiple comparison tests were performed using a least significant difference (LSD), suitable for factorial design, at $95 \%$ of confidence level. Statistical calculation and analysis were performed using Microsoft excel version 7.0. The yield of crude extract obtained under optimum condition was found to be $13.82 \%$.

\subsection{DPPH radical scavenging activity}

The relatively stable DPPH radical has been widely used to test the ability of a compound to act as free radical scavenger or hydrogen donor and thus to evaluate its antioxidant activity ( $\mathrm{Li}$ et al., 2008). Phenolic compounds in plants are viewed as powerful in vitro antioxidants due to their ability to donate hydrogen or electrons and to form stable radical intermediates (Wang et al., 2007). Plant extract quenched DPPH free radical in a dose-dependent manner. As concentration of the extract increased, its DPPH quenching activity also increased as shown in Fig. 2. The observed antioxidant activity of the extract may be due to the neutralization of free radical character of DPPH; either by transfer of an electron or hydrogen atom. The plant extract showed antioxidant activity in the DPPH assay with great antioxidant capacity and the $\mathrm{IC}_{50}$ occurred at $96.21 \pm 9.03 \mu \mathrm{g} / \mathrm{ml}$ of extract. The inhibitory potential of the plant extract was compared with known antioxidant (ascorbic acid) and the result was comparable as shown in Fig. 2.

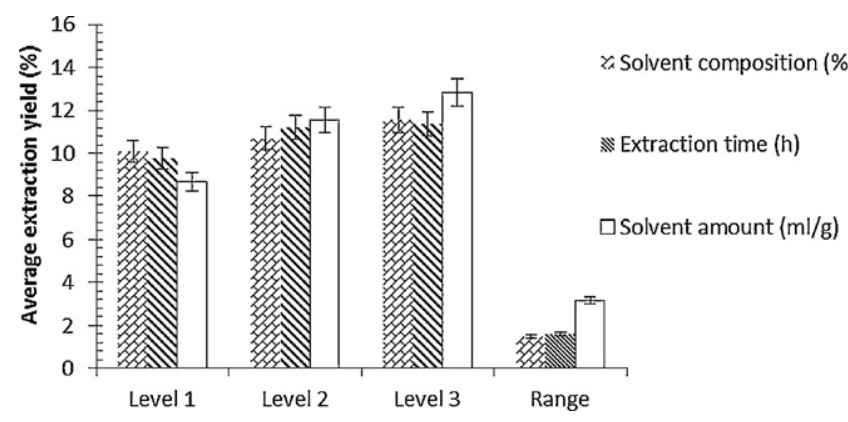

Fig. 1. Variation of extraction yields under complete randomized design (CRD) full factorial in different levels of factors: (a) solvent composition (\%), (b) extraction time (h) and (c) solvent to sample ratio ( $\mathrm{ml} / \mathrm{g})$ at $55^{\circ} \mathrm{C}$. 
Table 2

Calibration curves, correlation coefficients $\left(r^{2}\right)$, detection limits and quantification limits for HPLC analysis for compounds extracted, identified and quantified from Myrmecodia pendan.

\begin{tabular}{rlllr}
\hline Peak no. & Compounds & Linear equations & \multicolumn{1}{l}{$\begin{array}{l}\text { Squ. } \\
\text { correlation } \\
\text { coefficients }\left(r^{2}\right)\end{array}$} & \multicolumn{1}{c}{ LOD $^{\mathrm{a}}\left(\mu \mathrm{g} / \mathrm{ml}^{\mathrm{b}}(\mu \mathrm{g} / \mathrm{ml})\right.$} \\
\hline 8 & Kaepferol & $y=1.52 x-1.22$ & 0.977 & $0.460 \pm 0.033$ \\
7 & Luteoline & $y=0.39 x+0.04$ & $1.533 \pm 0.110$ \\
5 & Rutine & $y=85.5 x-0.03$ & $1.750 \pm 0.096$ & $0.720 \pm 0.066$ \\
10 & Quercetin & $y=0.3 x$ & 1 & $1.960 \pm 0.159$ \\
12 & Apigenin & $y=18.8 x+0.14$ & 0.995 & $0.670 \pm 0.075$ \\
\hline
\end{tabular}

a $\operatorname{LOD}(\mu \mathrm{g} / \mathrm{ml})=3 S$, where $S$ is the standard deviation of the blank determination $(n=3)$.

b $\operatorname{LOQ}(\mu \mathrm{g} / \mathrm{ml})=10 \times S$.

\subsection{Total phenolics and flavonoids contents}

Total phenol content was reported as gallic acid equivalents (GAE) by reference to standard curve $(Y=0.004 x+0.521$ and $\left.R^{2}=0.997\right)$. The dry plant extract has a total phenol content of $330.61 \pm 2.13 \mathrm{mg} G A E / g$. These observations suggest that sarang semut plant is rich in phenolics that have potential as value added products. Total flavonoid content was expressed as quercetin equivalents $(\mathrm{QE})$ by reference to standard curve $(Y=0.05 x-0.375$ and $R^{2}=0.991$ ). It was found that the extract has a total flavonoid content of $63.28 \pm 1.75 \mathrm{mg}$ QE/g of dry extract. Like any plant products, the total phenolic and flavonoids contents and the radical inhibitory effect can be influenced by the plant source and environment where the plant is collected and cultivated.

\subsection{Analysis of flavonoids by HPLC}

The extract from sarang semut obtained under optimum conditions $(80 \%$ ethanol as solvent, $50 \mathrm{ml}$ solvent per gram sample, extraction time $4 \mathrm{~h}$ ) was analyzed using HPLC at 280 and $285 \mathrm{~nm}$.

Five flavonoid compounds (kaempferol, luteoline, rutine, quercetine and apigenin) were identified from the extract by matching their retention times against those of the standards. Peak assignment was confirmed by injection of standards.

However, the results obtained in this work cannot be compared with those reported in literatures. Because firstly this study is the first work on the preliminary identification and quantification of this plant, and secondly the retention times depend on factors such as solvent composition, extract matrix and the gradient elution program. Fig. 3 shows the HPLC chromatogram of a mixture of eight flavonoid standards for peak comparison with the chromatogram of the crude plant extract (Fig. 4). As shown in Fig. 4, the HPLC chromatogram of the extract obtained under optimum conditions displays twelve peaks which were detected at $280 \mathrm{~nm}$. Peaks 4, 7, 9,

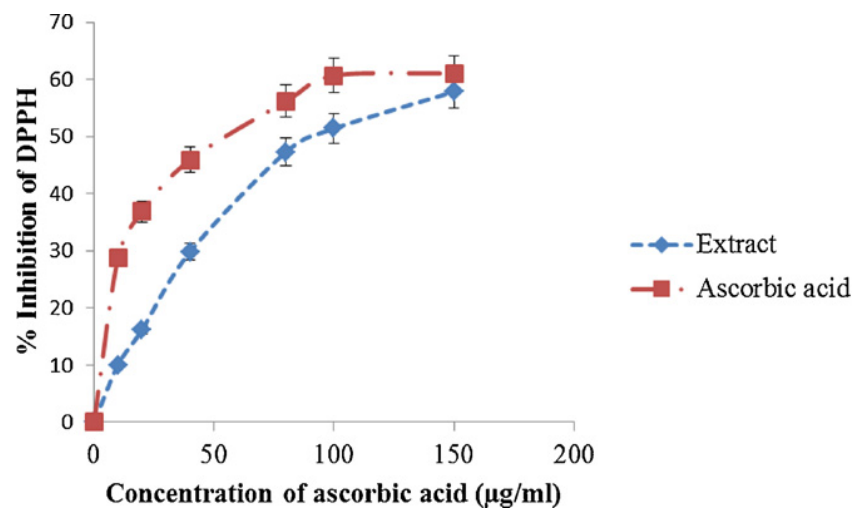

Fig. 2. DPPH radical scavenging capacity of plant extract and ascorbic acid. Data represent means $\pm \mathrm{SD}(n=3)$.
10 and 12 were identified as rutine, luteoline, kaepferol, quercetin and apigenin, respectively with good resolution.

All identified flavonoids were calibrated at $280 \mathrm{~nm}$. Five flavonoids including kaempferol, luteoline, rutine, quercetin and apigenin were quantified. Kaempferol was found to have the highest concentration $(13.767 \mathrm{mg} / \mathrm{g})$, followed by apigenin $(4.700 \mathrm{mg} / \mathrm{g})$. The other three all existed in relatively smaller concentrations; quercetin $(0.030 \mathrm{mg} / \mathrm{g})$, luteoline $(0.005 \mathrm{mg} / \mathrm{g})$, rutine $(0.003 \mathrm{mg} / \mathrm{g}$ ). All results (total phenolic content, total flavonoid, individual flavonoids as well as the radical inhibitory effect) shown in this study may vary depending on the source of sarang semut as well as the environment where it is cultivated.

The summary of linear equations, squared correlation coefficients, limit of determination (LOD) and limit of quantification (LOQ) of the five quantified flavonoids are presented in Table 2.

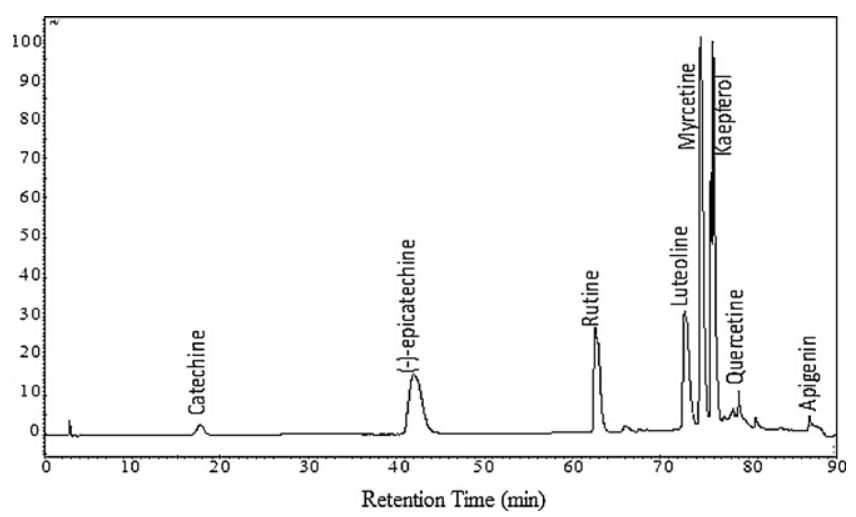

Fig. 3. Chromatogram of eight available flavonoid standards monitored at $280 \mathrm{~nm}$ and identified with retention time ( $\mathrm{min})$ catechin (17.593), (+)-epicatechin (43.110), rutine (62.433), luteoline (73.178), myrcetin (74.777), kaepferol (76.197), quercetin (78.147) and apigenin (87.160).

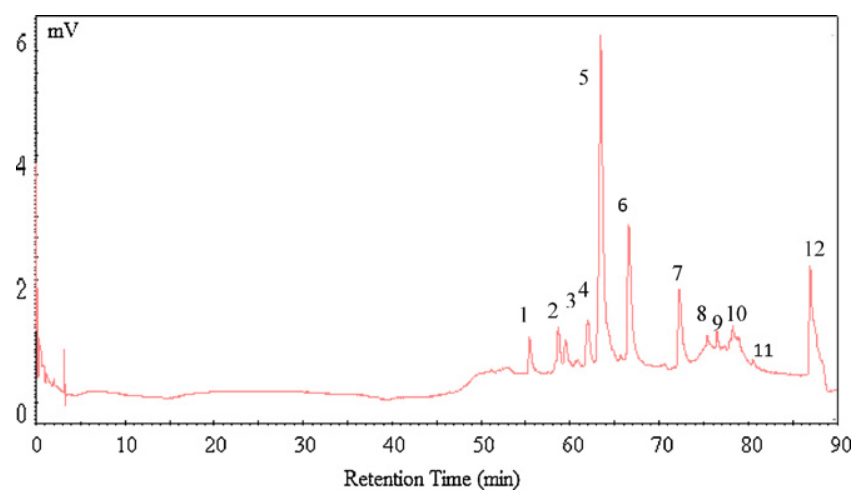

Fig. 4. HPLC chromatogram of the crude extract obtained under optimum conditions: $80 \%$ ethanol, $4 \mathrm{~h}$ and $50 \mathrm{ml}$ per gram sample. Peak no. 4 (rutine), 7 (luteolin), 9 (kaepferol), 10 (quercetin) and 12 (apigenin) were identified peaks. 


\section{Conclusion}

This investigation has showed that water bath extraction method at constant temperature $\left(55^{\circ} \mathrm{C}\right)$ and optimum conditions of solvent composition (80\% ethanol), extraction time $(4 \mathrm{~h})$ and solvent $/ \mathrm{g}$ sample $(50 \mathrm{ml})$, resulted maximum yield (13.82\%). The extract was evaluated for radical-scavenging activity (1,1-diphenyl-2-picryldrazyl radical). The extract showed radical scavenging activity ( $\mathrm{IC}_{50}$ value of $96.21 \pm 9.03 \mu \mathrm{g} / \mathrm{ml}$ ) and its quenching activity was comparable to that of ascorbic acid. The total phenol and flavonoid contents of sarang semut $(M$. pendans) extract were found to be $330.61 \pm 2.13 \mathrm{mg} \mathrm{GAE} / \mathrm{g}$ and $63.28 \pm 1.75 \mathrm{mg} \mathrm{QE} / \mathrm{g}$ of dry extract, respectively. From HPLC analysis of crude extract, five flavonoids including kaempferol $(13.767 \mathrm{mg} / \mathrm{g})$, luteolin $(0.005 \mathrm{mg} / \mathrm{g})$, rutine $(0.003 \mathrm{mg} / \mathrm{g})$, quercetin $(0.030 \mathrm{mg} / \mathrm{g})$ and apigenin $(4.700 \mathrm{mg} / \mathrm{g})$ were identified and quantified in this plant. Hence the plant can be considered as a potential source for flavonoids particularly and phenolic compounds generally. The findings from this work may add to the overall value of the medicinal potential of plants.

\section{Acknowledgment}

This work was supported by National Taiwan University of Science and Technology through a grant (100H451403).

\section{References}

Abrham, L.C.N., Masakuni, T., Isao, H., Hajime, T., 2008. Antioxidant flavonoid glycosides from the leaves of Ficus fumila L. Food Chemistry 109, 415-420.

Ajila, C.M., Rao, L.J., Rao, U.J.S.P., 2010. Characterization of bioactive compounds from raw and rip Mangifera indica L. peel extracts. Food and Chemical Toxicology 48 , 3406-3411.

Androutsopoulos, V.P., Papakyriakou, A., Vourloumis, D., Tsatsakis, A.M., Spandidos, D.A., 2010. Dietary flavonoids in cancer therapy and prevention: substrate and inhibitors of cytochrome p450CYP1 enzymes. Pharmacology \& Therapeutics 126, 9-20.

Barontini, M., Bernini, R., Crisante, F., Fabrizi, G., 2010. Selective and efficient oxidative modifications of flavonoids with 2 -iodoxybenzoic acid (IBX). Tetrahedron 66, 6047-6053.

Barreca, D., Bellocco, E., Caristi, C., Leuzzi, U., Gattuso, G., 2011. Distribution of C- and O-glycosyl flavonoids (3-hydroxy-3-methylglutaryl)glycosyl flavanones and furocoumarins in Citrus aurantium L. juice. Food Chemistry 124, 576-582.

Basma, A.A., Zakari, Z., Latha, L.Y., Sasidharan, S., 2011. Antioxidant activity and phytochemical screening of the methanol extracts of Euphorbia hirta L. Asian Pacific Journal of Tropical Medicine 4, 386-390.

Biesaga, M., 2011. Influence of extraction methods on stability of flavonoids. Journal of Chromatography A 1218, 2505-2512.

Boue, S.M., Carter-Wientjies, C.H., Shih, B.Y., Cleveland, T.E., 2003. Identification of flavones aglycones and glycosides in soybean pods by liquid chromatography-tandem mass spectroscopy. Journal of Chromatography A 991 , 61-68.

Chiu, K.-L., Cheng, Y.-C., Chen, J.-H., Chang, C.J., Yang, P.-W., 2002. Super critical fluids extraction of ginkgo ginkgolides and flavonoids. Journal of Supercritical Fluids 24, 77-87.

Erlund, I., 2004. Review of the flavonoids quercetin, hesperetin, and naringenin. Dietary sources, bioactivities, bioavailability, and epidemiology. Nutrition Research 24, 851-874.

Heim, K.E., Tagliaferro, A.R., Bobilya, D.J., 2002. Flavonoid antioxidants; chemistry, metabolism and structure-activity relationships. The Journal of Nutritional Biochemistry $13,572-584$.

Li, Y., Jiang, B., Zhang, T., Mu, W., Liu, J., 2008. Antioxidant and free radical-scavenging activities of chickpea protein hydrolysate (CPH). Food Chemistry 106, 444-450.

Lisa, M.S., Rahman, R.A., Mandana, B., Jinap, S., Rahmat, A., Zaidul, I.S.M., Hamid, A., 2010. Supercritical carbon dioxide extraction of bioactive flavonoids from Strobilanthes crispus (pecah Kaca). Food and Bioproducts Processing 88, 319-326.

Marston, A., 2007. Role of advances in chromatographic techniques in phytochemistry. Phytochemistry 68, 2785-2797.

Martens, S., Mithofer, A., 2005. Flavones and flavones syntheses. Phytochemistry 66, 2399-2407.

Merken, H.M., Beecher, G.R., 2000. Liquid chromatographic method for the separation and quantification of prominent flavonoid aglycones. Journal of Chromatography A 897, 177-184.

Michel, T., Destandau, E., Elfakir, C., 2011. Evaluation of a simple and promising method for extraction of antioxidants from sea buckthorn (Hippophae rhamnoides L.) berries. Pressurized solvent-free microwave assisted extraction. Food Chemistry 126, 1380-1386.

Mladenka, P., Zatloukalova, L., Filipsky, T., Hrdina, R., 2010. Cardiovascular effects of flavonoids are not caused only by direct antioxidant activity. Journal of Free Radicals in Biology \& Medicine 49, 963-975.

Plochmann, K., Korte, G., Koutsilieri, E., Richling, E., Riederer, P., Rethwilm, A. Schreier, P., Scheller, C., 2007. Structure-activity relationships of flavonoidsinduced cytotoxicity on human leukemia cells. Archives of Biochemistry and Biophysics 460, 1-9.

Prochazkova, D., Bousova, I., Wilhelhelmova, N., 2011. Antioxidant and prooxidant properties of flavonoids. Fitoterapia 82, 513-523.

de Rijke, E.D., Out, P., Niessen, W.M., Ariese, F., Gooijer, C., Brinkman, U.A., 2006 Analytical separation and detection methods of flavonoid. Journal of Chromatography A 1112, 31-63.

Seyoum, A., Asres, K., El-Fiky, F.K., 2006. Structure-radical scavenging activity relationships of flavonoids. Phytochemistry 67, 2058-2070.

Soeksmanto, A., Subroto, M.A., Wijaya, H., Simanjuntak, P., 2010. Anticancer activity test for extracts of sarang semut plant (Myrmecodia pendens) to HeLa and MCMB2 cells. Pakistan Journal of Biological Sciences 13, 148-151.

Tian, X.-J., Yang, X.-W., Yang, X., Wang, K., 2009. Studies of intestinal permeability of 36 flavonoids using Caco-2 cell monolayer model. International Journal of Pharmaceutics 367, 58-64.

Wang, J., Yuan, X., Jin, Z., Tian, Y., Song, H., 2007. Free radical and reactive oxygen species scavenging activities of peanut skins extract. Food Chemistry 104 , 242-250.

Weisz, G.M., Kammerer, D.R., Carle, R., 2009. Identification and quantification of phenolic compounds from sun flower (Helianthus annuus L) kernels and shells by HPLC-DAD/ESI-MS. Food Chemistry 115, 758-765.

Xiao, W., Han, L., Shi, B., 2008. Microwave-assisted extraction of flavonoids from Radix astragali. Separation and Purification Technology 62, 614-618.

Zin, Z.M., Abdul-Hamid, A., Osman, A., 2002. Anti oxidative activity of extracts from mengkudu (Morinda citrifolia L.) root fruit and leaf. Food Chemistry 78 $227-232$. 